under the Board of Trustees was 24,585, excluding natives, and in the year ending December 31, 1937, 23,501.

\section{The Carnegie United Kingdom Trust}

So all-pervasive are the Trust's activities that its annual report (Twenty-fourth Annual Report, January-December 1937, approved by the Trustees at their General Meeting held on Friday, March 4, 1938. Pp. vi $+92+2$ plates. Dunfermline: Carnegie United Kingdom Trust) is almost equivalent to an index to all organized voluntary effort toward social amelioration. It is noteworthy that a very large proportion of the enterprises favoured by the Trust are concerned with rural life : land settlement, rural community councils, village halls, survey of Scottish villages, local history records, schools for rural music conductors, young farmers' clubs, women's institutes, youth hostels, Y.M.C.A. farm-training scheme, village colleges, women's rural institutes' handicrafts scheme. Land settlement schemes, for which the Trust allocated $£ 150,000$ for the period 1936-40, progressed steadily last year. The Land Settlement Association now controls twenty-five estates in fifteen English counties, comprising 11,000 acres and providing, when fully developed, small-holdings for 7,000 persons, all taken from distressed areas. The settlers who are definitely established are happy in their surroundings and are mixing more and more with the old inhabitants of neighbouring villages, and the general health, especially of the children, has shown notable improvement. The Association is, however, finding it difficult to induce local authorities to make use of the powers vested in them. For many years, the Trust has fostered the development of agencies for caring for the welfare of boys and girls over fourteen years of age. Among these are the National Association of Boys' Clubs and the National Council of Girls' Clubs, which are in receipt of subsidies from the Trust amounting to $£ 25,000$ for the current quinquennium. Valuable as the work of these clubs undoubtedly is, it is very small in volume when compared with the corresponding activities in Germany and Italy.

\section{The Agricultural Research Council}

FARMERS and others interested in agriculture have sometimes expressed the view that insufficient information is available about the activities of the Agricultural Research Council. To meet what it recognizes as an important need, the Council has issued a booklet entitled "Constitution and Functions of the Agricultural Research Council", copies of which can now be obtained on written application to the Secretary at 6a, Dean's Yard, Westminster, S.W.1. The Council, which was established by Royal Charter in 1931, is responsible for tendering advice to the Ministry of Agriculture and Fisheries, the Department of Agriculture for Scotland and the Development Commissioners as to the expenditure on agricultural research of State funds amounting to more than four hundred thousand pounds yearly. It is also charged with the scientific supervision of subsidized agricultural research, and, in addition, it has research officers engaged in the investigation of particular problems. A recent development has been the acquisition of an estate at Compton in Berkshire for use as a field station. Here problems such as those involved in certain diseases of animals will be investigated on a field scale, when the necessary laboratory experiments have been carried out at the research institutes, and a supply of animals, which have been raised in isolation and are free from disease, will be kept available for the workers at these institutes. In addition to advising on research in progress, the Council plans and co-ordinates such immediate extensions of the research programme as seem necessary to secure a more intensive attack on problems of special urgency, particularly in the field of animal and plant diseases.

\section{Nomenclature in Electrical Engineering}

Trez development of electrical science and its applications during the last century has led to the introduction of a host of names, units and definitions, many of them now household words. The history of these words, and of others which have been introduced, only to be discarded, is of considerable interest, and recalls the difficulties the pioneers experienced in explaining clearly new facts and phenomena: Though many terms go back to Greek science and to the sixteenth, seventeenth and eighteenth centuries, the majority belong to the last century and the days since Faraday. The subject is an intricate one and it has not, we believe, been dealt with before so fully as by Prof. G. W. O. Howe, in a paper entitled "The Concepts and Language of Electrical Engineering" read to the Association of Engineers at Calcutta, and printed in the Engineer of September 2. In coining the words anode, cathode, ions, electrodes and others, Faraday was assisted by Dr. Whewell of Cambridge, whose encyclopædic knowledge led someone to write, "You may roam where you will through the realm of infinity, and find nothing so great as the Master of Trinity". Whewell had proposed the terms inductricity and inducteous, which fortunately, like the mac, bob, tom and dick of Heaviside, were not adopted. Prof. Howe does justice to the various individuals who have devoted their attention to the matter of units, as well as to the committees and congresses which have assisted in standardizing them.

\section{Indian Forest Research}

THE value of forestry research work in its direct bearing upon other Government departments and industry is admirably portrayed in a publication entitled "Forest Research and Indian Industry", issued by the Government of India Press, New Delhi. Experts are maintained at the Forestry Research Institute at Dehra Dun to undertake research work in sylviculture, botany, mycology, forest protection, entomology, biochemistry, forest utilization, wood technology, timber seasoning, preservation and testing of timbers, wood-working and minor forest products including paper pulp. The work of these experts often interlocks, as becomes evident from a perusal of this very informative publication. Illustrative of some of the 
sylvicultural work undertaken at the Institute is a recent paper in sylviculture entitled "Seed Weights, Plant Percents, etc., for Forest Plants in India", by J. N. Sen Gupta (Ind. Forest Records, New Series, Sylvic., 2, No. 5, Government of India Press, New Delhi, 1937). In this paper the author gives data for the date of collection, seed weight, germinative capacity and germination per cent of 505 tree species, including 52 exotics, from all parts of India. In the botany section, Mr. C. E. Parkinson published two numbers dealing with Indian tree species in the Indian Forest Records, New Series, Botany (Govt. of India Press, New Delhi, 1937). The first (1, No. 1) deals with the important Indian Terminalia of the section Pentaptera, comprising trees of forest and economic importance. Four species with three varieties and nine forms are recognized. No. 2 of vol. 1 is devoted to part 4 of "Illustrations of Indian Forest Plants", the paper dealing with five species of the family Dipterocarpacece.

\section{Broadcasting Station LS-I, Buenos Aires}

THe broadcasting station LS-1, belonging to the municipality of Buenos Aires and situated about 20 miles from the city, has recently been re-equipped and is now one of the most powerful in South America. The antenna is the tallest vertical broadcast radiator in South America, being 778 feet high. It uses the new shunt excitation method developed by the Bell Telephone Laboratories, a full description of which is given in their quarterly Journal of July. The ground system consists of 120 buried radials, each 670 feet long, with an equal additional number of radials each 280 feet in length. Power is fed on to the antenna system through a $62-0 h m$ nitrogen gas filled, concentric copper tube transmission line, 640 feet long. The station is operated under the administration of the Colon Theatre of Buenos Aires, which is one of the world's finest opera houses, where many of the world's leading artists are heard each season. There are 16 hours of transmission daily, with a varied programme of widely international flavour and cultural and educational subjects. Its main feature is the complete transmission of the opera and other musical activities of the Colon Theatre. The Colon season was officially opened this year by the President of the Republic on May 23, and can now be heard by the great majority of the population of Argentina as well as by listeners in Chile, Uruguay and southern Brazil. A wide repertory of classic Italian, German and Russian opera has been presented in addition to a few modern Argentine works. The new studios are built below ground-level and close to the Colon Theatre and are completely sound insulated. From the broadcasters' point of view the economy and ease of operation have set up new standards. The audio-frequency response does not vary more than one decibel between 30 and 10,000 cycles. The audio-distortion is less than 5 per cent even at complete modulation. Provisions have been made for increasing the output of the 50 kilowatt transmitter to $500 \mathrm{kw}$. by the addition of a $500 \mathrm{kw}$. amplifier. The results obtained have more than equalled expectations.

\section{The Smithsonian Institution}

The report of the secretary of the Smithsonian Institution for the year ended June 30, 1937, refers to the improvement of the National Zoological Park by the completion of three new exhibition buildings, a machine shop, a garage and new heating and electric installations. An expedition to Sumatra to obtain specimens of the interesting animals of that region for the National Zoo was still in the field, but reports indicated that it was highly successful. In the Division of Radiation and Organisms, notable advances have been made in the studies of photosynthesis, phototropism and the action of ultra-violet rays on plant growth. The Astrophysical Observatory has continued its measurements of the solar constant of radiation, and a new method has been devised in place of the 'short method' reduction of observations, used since 1923, in which a flaw was discovered. The Smithsonian radio programme, a weekly half-hour presentation of the Institution's researches and activities, continued with undiminished popularity, and accessions to the Library for the year number 11,469 , mostly in exchange for the publications of the Institution. Appendixes include the report of the United States National Museum, the National Collection of Fine Arts, the Freer Gallery of Art and of the several divisions of the Institution.

\section{Smallpox Vaccination in an Indian Epidemic}

A strikrng instance of the protection against smallpox afforded by vaccination is given in the annual report for 1936 of the All-India Institute of Hygiene and Public Health, Calcutta, recently published. During the smallpox epidemic that occurred in the first quarter of 1936, there were 604 infants and children less than five years of age on the roll of the Maternity and Child Welfare Section of the Institute. Of these children, 434 were vaccinated before or during the epidemic, and 170 were not vaccinated. Of the unvaccinated, 42 developed the disease, a case incidence of $\mathbf{2 4 . 7}$ per cent, of whom 17 died, a mortality of 10 per cent for the group, or of 38.5 per cent of the cases. In the vaccinated group, 10 developed the disease in less than a week after vaccination and before protection had developed, of whom 7 died. Excluding these cases, of the remaining 424 vaccinated efficiently, only 3 contracted the disease and all recovered, an incidence of 0.7 per cent with mortality nil.

\section{Gastro-Enteritis Conveyed by Raw Milk}

As outbreak of food-poisoning occurred at Wilton, in Wiltshire, in October 1936 and was limited to consumers-chiefly children-of a particular supply of bottled raw milk ("A Report on an Outbreak of Food Poisoning due to Salmonella, Type 'Dublin' and Conveyed by Raw Milk". By E. T. Conybeare and L. H. D. Thornton. Reps. on Pub. Health and Med. Subjects, No. 82. Ministry of Health, 1938. H.M. Stationery Office. 2d. net). The attack of illness commenced in 12-24 hours after consumption of the milk, the chief symptoms being headache, nausea and vomiting, and later diarrhca, persisting for 1-3 days, 